\title{
Review Teknologi Simple Phenotyping sebagai Database Pengembangan Robot Pendeteksi dan Pemupuk Nitrogen Padi
}

\author{
Mohammad Syafii ${ }^{*}$, M. Haidar Rozik ${ }^{1}$, Airlanggia Febi Torimania ${ }^{1}$, Janan Nabilah Nur Indriana \\ ${ }^{1}$ Fakultas Pertanian Universitas Trunojoyo Madura \\ Jl. Raya Telang No 02 Kamal Bangkalan Madura 69162 Jawa Timur \\ *m.syafii@trunojoyo.ac.id \\ DOI: https://doi.org/10.21107/rekayasa.v14i2.10709
}

\begin{abstract}
Rice is one of the most important staple food consumed by more than half of the world population, especially in Indonesia where majority of the people consumed rice as daily intake. Precision agriculture is needed to boost production to meet the demand. As limiting factor for plant growth, huge doses of nitrogen fertilizer are deployed, in fact the absorbtion rate of plant was only about 50\%. Developing vision-control based robot for fertilizing plant need proper database so that false positive and negative could be avoided. Several previous methods that were available to assest nitrogen status in plant such as a color chart, spectrometer, SPAD-502, and kjedahl. Plant phenotyping is often used for plant breeding, but also very useful in determining nutrient status in plants. Cheap and simple phenotyping using digital camera followed by extracting data through open source platform such as ImageJ can be very useful to generate data for building the database. Here we presented the current progress on plant phenotyping for nitrogen assessment in plant as well as an ImageJ in phenomic era. We also highlight some robotic progress especially vision-based robot, who rely on proper imaging data for their training.
\end{abstract}

Keywords : image-J, camera digital, phenomics, robotik

\section{PENDAHULUAN}

Padi merupakan salah satu komoditas pangan penting karena merupakan makanan pokok mayoritas penduduk Indonesia. BPS (2017) melaporkan bahwa total konsumsi beras pada tahun 2017 mencapai 29.18 juta ton, dan diproyeksikan terus meningkat seiring bertambahnya jumlah penduduk. Jumlah penduduk Indonesia diproyeksikan meningkat sampai 305 juta jiwa pada tahun 2035 dari sebelumnya hanya sebesar 238.5 juta jiwa (BPS 2013). Peningkatan jumlah penduduk tidak selalu diimbangi dengan meningkatnya produksi padi. Produksi padi nasional pada tahun 2018 diperkirakan hanya sebesar 56.54 juta ton gabah kering giling (GKG), jauh dibandingkan produksi padi di tahun 2015 yaitu sebesar 75.4 ton GKG (BPS 2018).

Pemenuhan meningkatnya kebutuhan pangan membutuhan peningkatan pemenuhan nutrisi tanaman, dan nitrogen merupakan nutrisi paling utama (Dimkpa et al., 2020). Nitrogen merupakan

\section{Article History:}

Received: April, 19 ${ }^{\text {th }} 2021 ;$ Accepted: June, $27^{\text {th }} 2021$ Rekayasa ISSN: 2502-5325 has been Accredited by Ristekdikti (Arjuna) Decree: No. 23/E/KPT/2019 August 8th, 2019 effective until 2023 faktor pembatas utama pertumbuhan tanaman setelah air (Nag et al., 2019). Nitrogen juga merupakan komponen utama dari klorofil dan protein yang sangat berkaitan erat dengan warna daun, status pertumbuhan tanaman, dan hasil (Fageria et al., 2011). Kekurangan nitrogen akan menyebabkan lebih kecilnya ukuran daun, kandungan klorofil yang lebih rendah, produksi biomassa lebih rendah, serta menurunkan jumlah dan kualitas biji (Adhikari et al., 1999). Di atmosfer sendiri nitrogen sangat melimpah yaitu mencapai $78 \%$, namun dalam bentuk dinitrogen (N2) sehingga tidak dapat secara langsung digunakan oleh tanaman karena ikatan kovalen rangkap tiga antara dua atom (Khan et al., 2019). Untuk memenuhi kebutuhan nitrogen bagi pertumbuhan tanaman, pupuk anorganik buatan industri digunakan secara intensif (Mahmud et al., 2020).

\section{Cite this as:}

Syafii, M., Rozik, M.H., Torimania, A.F \& Indriana, J.N.N. (2021). Review Teknologi Simple Phenotyping sebagai Data Base Pengembangan Robot Pendeteksi dan Pemupuk Nitrogen Padi. Rekayasa 14 (2). 175-182. doi: https://doi.org/10.21107/rekayasa.v14i2.10709.

(C) 2021 Mohammad Syafii 
Penggunaan nitrogen anorganik ini membutuhkan energi besar sekaligus sumber polusi dan penghasil emisi gas rumah kaca (Bloch et al., 2020). Hal tersebut dikarenakan serapan nitrogen tanaman dari pemupukan masih belum efisien yaitu sekitar $50 \%$, sehingga sisa yang tidak terserap seperti ammonia, nitrat, dan N2O akan terlepas ke alam dan mencemari lingkungan (Coskun et al., 2017). Diantara elemen lingkungan yang ada, tanah merupakan elemen yang paling terdampak oleh penggunaan dosis pupuk berlebih. Dosis tidak tepat serta jenis pupuk yang digunakan mengakibatkan akumulasi garam yang membuat resiko peningkatan asidifikasi atau salinitas tanah (Mikula et al., 2020).

Selain memiliki pengaruh buruk ke lingkungan, ketergantungan terhadap pupuk nitrogen anorganik memiliki masalah lain yaitu seringnya terjadi kelangkaan pupuk pada periode di mana ketersediaannya sangat dibutuhkan. Pada budidaya padi pengeluaran biaya produksi terbesar setelah upah tenaga kerja dan jasa pertanian ialah biaya pemupukan yaitu sebesar $9.43 \%$, atau sekitar 1.28 juta rupiah per hektarnya (BPS, 2017). Upaya mengefisiensikan penggunaan pupuk anorganik selain bermanfaat bagi lingkungan, juga akan meningkatkan pendapatan petani karena biaya produksi dapat ditekan. Dilain pihak konsistensi peningkatan produksi padi sangat diperlukan untuk memastikan ketahanan pangan di Indonesia. Manajemen budidaya tanaman melalui pertanian presisi (precision agriculture) merupakan salah satu upaya untuk mewujudkan hal tersebut.

Cisternas et al., (2020) melakukan studi sistematik review dan menemukan bahwa dari 23 aplikasi pertanian presisi yang telah dipublikasikan, mayoritas tanaman yang ditargetkan ialah jagung, tebu, gandum, kapas, anggur dan kedelai. Target penerapan pertanian presisi pada komoditas tersebut juga bergaram diantaranya kontrol gulma dan hama serta penyakit tanaman, pemupukan, pemanenan, irigasi dan juga penanaman. Chawade et al.,(2019) mengemukakan bahwa pemanfaatan teknologi phenotyping dalam pertanian presisi berbeda dengan pemanfaatannya dalam bidang pemuliaan tanaman. Phenotyping dalam pemuliaan lebih diarahkan untuk melihat penampakan fenotipe yang ditargetkan, sedangkan dalam pertanian presisi lebih diarahkan pada monitoring kebutuhan pemupukan dan kontrol gulma.

Berbagai metode imaging dalam kegiatan phenotyping tanaman untuk membangun pertanian presisi mulai dikembangkan menggunakan berbagai pendekatan seperti spektroskopi, fluorescence, thermal infrared, visible light (Lakshmi \& Sivakumar, 2019). Menurut Pratab et al., (2019) analisis berbasis gambar digital mampu menyediakan data dalam waktu cepat dengan kelebihan mudah direkam, ditransmisikan, dan disimpan dalam database. Pengembangan dan inovasi lebih lanjut dari teknologi ini dapat dilakukan dengan menggunakan berbagai perangkat pendukung seperti drone untuk memonitoring pertumbuhan dan fungsi tanaman menggunakan komputasi dan machine learning dalam prosesing gambar dan ekstraksi informasinya (Hickey et al., 2019). Artikel review ini membahas tentang penggunaan teknologi phenotyping sederhana yang dapat diaplikasikan untuk membangun database yang lebih simpel dan murah dalam perkembangan pertanian presisi menggunakan robotik.

\section{METODE DETEKSI KETERSEDIAAN NITROGEN}

Untuk mengetahui status ketersediaan nitrogen pada tanaman, dapat dilakukan menggunakan beberapa pendekatan, baik menggunakan metode destruktif maupun non-destruktif (Tabel 1.). Rangkuman penggunaan metode deteksi status ketersediaan nitrogen juga dirangkum pada Gambar 1.

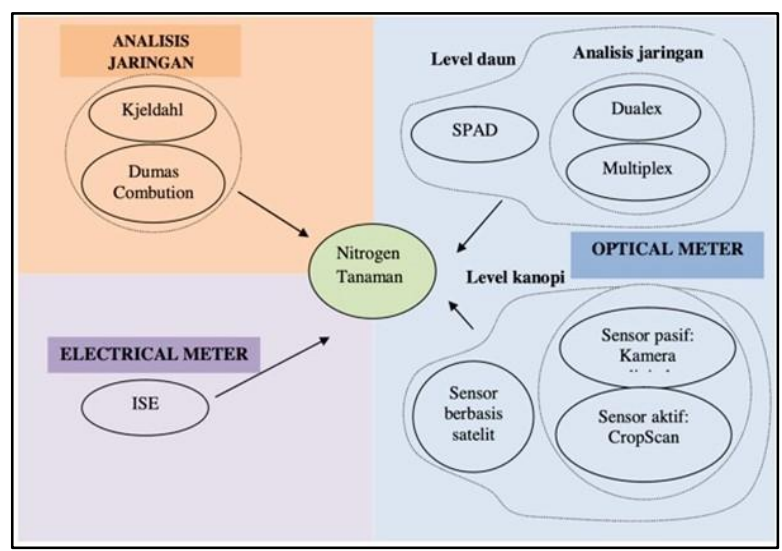

Gambar 1. Metode pengukuran nitrogen tanaman (Adaptasi dari Munoz-Huerta et al., 2013)

Metode berbasis analisis jaringan seperti kjeldahl merupakan metode yang digunakan secara luas untuk menguji kandungan nitrogen. Klorofil dan polifenol juga dapat dijadikan indikator status nitrogen pada tanaman. Alat yang digunakan ialah SPA- 502 untuk klorofil dan dualex untuk polifenol. 
Tabel 1. Perbandingan Pendekatan Pengukuran Status Ketersediaan Nitrogen

\begin{tabular}{|c|l|l|l|l|l|}
\hline No & $\begin{array}{l}\text { Pendekatan } \\
\text { pengujian }\end{array}$ & Metode & Tanaman & Kelemahan & Pustaka \\
\hline 1 & Kjeldahl & Destruktif & Umum & Waktu pengerjaan lama dan mahal & Munos-Huerta et al. 2013 \\
\hline 2 & Bagan warna daun & Non destruktif & $\begin{array}{l}\text { Padi, } \\
\text { gandum }\end{array}$ & Kurang akurat deibandingkan klorofil meter & Varinderpal-Singh et al. 2010 \\
\hline 3 & $\begin{array}{l}\text { Klorofil meter } \\
\text { (SPAD) }\end{array}$ & Non destruktif & $\begin{array}{l}\text { Padi, } \\
\text { gandum }\end{array}$ & Mengukur klorofil bukan nitrogen & Ata-Ul-Karim et al. 2016 \\
\hline 4 & Kamera digital & Non destruktif & Gandum & Akurasi sangat bergantung kondisi lingkungan & $\begin{array}{l}\text { Soucek et al. 2019; Baresel et } \\
\text { al. 2017 }\end{array}$ \\
\hline
\end{tabular}

Tabel 2. Perbandingan teknik imaging dalam aplikasi phenotyping tanaman (Diolah dari Li et al. 2014)

\begin{tabular}{|c|c|c|c|c|c|c|}
\hline Teknik & Lingkungan & Sensor & Resolusi & Data Mentah & Aplikasi & Keterbatasan \\
\hline \multirow[t]{2}{*}{$\begin{array}{l}\text { Visible } \\
\text { imaging }\end{array}$} & Terkendali & \multirow{2}{*}{$\begin{array}{l}\text { Kamera } \\
\text { sensitive } \\
\text { terhadap } \\
\text { spektrum } \\
\text { tampak }\end{array}$} & \multirow[t]{2}{*}{$\begin{array}{l}\text { Seluruh atau } \\
\text { sebagian organ, } \\
\text { time series }\end{array}$} & \multirow[t]{2}{*}{$\begin{array}{l}\text { Gray atau } \\
\text { gambar } \\
\text { berwarna }\end{array}$} & $\begin{array}{l}\text { Dinamika } \\
\text { pertumbuhan, } \\
\text { morfologi daun }\end{array}$ & $\begin{array}{l}\text { Hanya menyajikan } \\
\text { informasi fisiologi } \\
\text { tanaman }\end{array}$ \\
\hline & Lapang & & & & $\begin{array}{l}\text { Penutupan dan warna } \\
\text { kanopi, informasi } \\
\text { warna digunakan } \\
\text { untuk indikasi } \\
\text { kehijauan }\end{array}$ & $\begin{array}{l}\text { Tidak ada kalibrasi } \\
\text { spectrum, hanya } \\
\text { pengukuran relatif }\end{array}$ \\
\hline \multirow[t]{2}{*}{$\begin{array}{l}\text { Thermal } \\
\text { imaging }\end{array}$} & Terkendali & \multirow[t]{2}{*}{$\begin{array}{l}\text { Kamera near } \\
\text { infrared }\end{array}$} & \multirow{2}{*}{$\begin{array}{l}\text { Suhu permukaan } \\
\text { pada daerah } \\
\text { infrared }\end{array}$} & \multirow{2}{*}{$\begin{array}{l}\text { Potret } \\
\text { keseluruhan } \\
\text { tunas atau } \\
\text { jaringan daun }\end{array}$} & $\begin{array}{l}\text { Suhu permukaan, } \\
\text { konduktansi stomata }\end{array}$ & $\begin{array}{l}\text { Terkadang membutuhkan } \\
\text { kalibrasi sensor imaging }\end{array}$ \\
\hline & Lapang & & & & $\begin{array}{l}\text { Indeks luas daun dan } \\
\text { status Kesehatan } \\
\text { kanopi }\end{array}$ & $\begin{array}{l}\text { Sulit memisahkan suhu } \\
\text { tanah dan suhu tanaman }\end{array}$ \\
\hline \multirow[t]{2}{*}{$\begin{array}{l}\text { Imaging } \\
\text { spektroskopi }\end{array}$} & Terkendali & \multirow{2}{*}{$\begin{array}{l}\text { Kamera } \\
\text { infrared, } \\
\text { kamera } \\
\text { thermal }\end{array}$} & \multirow[t]{2}{*}{$\begin{array}{l}\text { Kanopi dan } \\
\text { vegetasi }\end{array}$} & \multirow[t]{2}{*}{$\begin{array}{l}\text { Indeks } \\
\text { vegetasi }\end{array}$} & $\begin{array}{l}\text { Indeks luas dan } \\
\text { komposisi biokimia } \\
\text { daun }\end{array}$ & $\begin{array}{l}\text { Mahal, interpretasi data } \\
\text { kompleks }\end{array}$ \\
\hline & Lapang & & & & $\begin{array}{l}\text { Konsentrasi pigmen } \\
\text { dan, indeks luas daun }\end{array}$ & $\begin{array}{l}\text { Membutuhkan kalibrasi } \\
\text { sensor, manajemen data }\end{array}$ \\
\hline \multirow[t]{2}{*}{ LiDAR } & Terkendali & \multirow[t]{2}{*}{$\begin{array}{l}\text { Laset dan } \\
\text { scanner }\end{array}$} & \multirow[t]{2}{*}{$\begin{array}{l}\text { Rekonstruksi } \\
\text { kanopi }\end{array}$} & \multirow[t]{2}{*}{ Model 3D } & $\begin{array}{l}\text { Estimasi indeks luas } \\
\text { daun, volume dan } \\
\text { biomassa }\end{array}$ & $\begin{array}{l}\text { Membutuhkan iluminasi } \\
\text { spesifik }\end{array}$ \\
\hline & Lapang & & & & $\begin{array}{l}\text { Estimasi indeks luas } \\
\text { daun, volume dan } \\
\text { biomassa }\end{array}$ & $\begin{array}{l}\text { Membutuhkan integrasi } \\
\text { GPS untuk georefensing }\end{array}$ \\
\hline
\end{tabular}

Beberapa perangkat yang telah dikembangkan baik deteksi pada permukaan seperti CropScan atau melalui satelit yang berbasis remote sensing. Beberapa peneliti juga telah mengembangkan sistem baru dalam menduga status nitrogen tanaman berbasis kamera digital (Munos-Huerta et al. 2013).

Penggunaan Metode Kjeldahl dalam menentukan status nitrogen merupakan yang paling akurat karena secara langsung mengukur nitrogen dalam jaringan tanaman. Meskipun demikian penggunaan metode ini bersifat destruktif serta harus dilakukan di dalam laboratorium, sehingga lama dalam pengerjaan serta biaya analisnya mahal. Penggunaan metode nondestruktif lebih diminati karena tidak harus merusak jaringan sampel. Abu et al., (2017) melaporkan bahwa pada metode konvensional rekomendasi pemupukan gandum sebesar 250 kg.ha-1 sedangkan apabila menggunakan BWD hanya merekomendasikan $200 \mathrm{~kg} \cdot \mathrm{ha}^{-1}$. Semenjak bagan warna daun menggunakan indikator berbagai warna pada objek kertas khusus, keberhasilan pendekatan ini sangat subjektif.

Metode non destruktif lain yang memiliki akurasi lebih baik dari bagan warna daun ialah klorofil meter. Pada tanaman gandum, berdasarkan analisis regresi diketahui kandungan klorofil berhubungan signifikan dengan kandungan nitrogen $\left(R^{2}=0.929\right)$. Selain dengan nitrogen, kandungan klorofil berhubungan dengan hasil (Monostori et al., 2016). Lebih lanjut, Zhao et al., (2016) juga menemukan bahwa kandungan klorofil dan $\mathrm{N}$ barley meningkat seiring dengan meningkatnya pemupukan N. Pada tanaman padi korelasi antara klorofil dan $\mathrm{N}$ menunjukkan model yang dipakai dapat secara andal memprediksi status nitrogen $\left(R^{2}=0.69999\right.$ 0.911.P<0.01). Penggunaan klorofil meter memiliki kekurangan utama yaitu tidak dapat mendeteksi kelebihan aplikasi pemupukan karena saturasi klorofil. Penggunaan klorofil meter juga dilakukan berdasarkan sampel terbatas, selain itu penggunaannya yang dilakukan secara manual membuat pengerjaan pendeteksian nitrogen pada 
lahan luas membutuhkan tenaga dan waktu yang lama.

\section{Phenotyping Untuk Mengukur Status Nitrogen}

Phenotyping tanaman merujuk pada deskripsi kuantitatif dari anatomi, ontogeny, fisiologi, dan kandungan biokimia tanaman. Bidang ini juga telah berkembang lebih luas dari hanya karakterisasi sifat tanaman pada kondisi lingkungan terkontrol ke arah lingkungan lapang (Walter et al., 2015). Sebanyak 1,827 artikel berkaitan dengan phenotyping, telah terpublikasi pada 145 jurnal, dengan jumlah tertinggi di jurnal Frontier Plant Science (87 artikel), Journal of Experimental Botany (83 artikel), Plant Methods (72 artikel) (Costa et al. 2020).

Berbagai metode phenotyping telah berkembang saat ini mulai dari yang menargetkan daun, akar, secara destruktif atau non destruktif (Tabel 2). Instrumen canggih pendukung kegiatan phenotyping saat ini juga telah dikembangkan untuk meningkatkan jumlah tanaman yang dapat di-fenotipyng-kan per set penelitian (Roitsch et al., 2019). Phenotyping jagung pada kondisi kekurangan nitrogen menggunakan remote sensing telah dilakukan oleh Lakshmi \& Sivakumar (2019). Berdasarkan perbandingan data RGB yang diekstrak dengan klorofil menggunakan SPAD-502, korelasi terkuat dengan produksi ialah hue, greener green area (GGA), korelasi kuat juga ditemukan pada RGB dengan klorofil.

Penggunaan kamera digital memiliki keunggulan utama yaitu simpel. Pada tanaman gandum Baresel et al., (2017) mendapatkan bahwa penggunaan kamera digital untuk mengetahui status nitrogen memiliki tingkat akurasi yang mirip dibandingkan pengukuran menggunakan pengukuran spectral, atau dengan kandungan klorofil menggunakan SPAD-502. Pada tanaman kopi robusta, Putra et al., (2018) menduga status kandungan klorofil a dan b, karotenoid, dan nitrogen tanaman kopi mengggunakan kamera digital dan membandingkannya dengan SPAD-502, spectrometer, dan Kjeldahl. Data seperti NDVIrgb (Normalized different vegetation index RGB), SR RGB (simple ratio intensity R-GB), Hue, VARI (Visible atmospherically resistance index), BRAVI (blue-red adjusted vegetation index), BRAVI-SR (BRAVI simple ratio), EVIgreen (Enhance vegetation index-green) direkomendasikan untuk menduga klorofil a dan $b$, karotenoid, dan level nitrogen melalui kamera digital.
Penggunaan kamera digital komersil yang simpel dan murah menjadi keunggulan dalam kegiatan pembangunan database pendugaan nitrogen secara langsung maupun tidak langsung melalui kandungan klorofil dalam kegiatan phenotyping. Keterbatasan yang dapat mengurangi akurasi seperti fluktuasi cahaya dapat diminimalisasi melalui pengujian menyeluruh mulai dari berbagai tahap pertumbuhan tanaman, pada kondisi terkontrol dan pada beberapa kondisi di lapang seperti cerah, berawan, dan mendung.

\section{Pemanfaatan Image-J untuk Ekstraksi Data Gambar}

Penggunaan perangkat open source yang tersedia seperti Image-J untuk mengektraksi data gambar dapat menjadi salah satu alternatif untuk membangun database. Image-J merupakan aplikasi yang digunakan untuk mengukur sifat fenotipe tanaman (Lakshmi \& Sivakumar 2019). Image-J memiliki keunggulan dalam kemudahanan mengoperasikannya. Perkembangan penggunaan Image-J sangat pesat, salah satunya karena sistemnya yang open source sehingga dapat dengan mudah ditelusuri, dimodifikasi, dan diredistribusi. Penggunaan Image-J sangat beragam mulai untuk visualisasi data dan materi pembelajaran, sampai prosesing gambar yang advance serta analisis statistiknya (Schindelin et al., 2015). Tanaman lain dapat dengan mudah ditambahkan ke dalam software, dan faktor penggangu lainnya yang dapat muncul pada tanaman (Polder et al., 2012).

Salah satu pengembangan perangkat Image-J ialah package FIJI yang dikembangkan untuk menjawab kebutuhan perangkat yang mudah diinstal. Project ini berkolaborasi dengan project serupa (berbasis Image-J) seperti Bio-Formats, ImageJ2, dan ImgLib untuk mencegah terjadinya duplikasi (Rueden \& Eliceiri 2019). Kevaufer et al., (2017) membandingkan penggunaan UAV sebagai perangkat untuk mendapatkan data gambar melalui kamera konvensional ImageJ di lapang pada kegiatan high throughput phenotyping (HTTP) untuk studi dua varietas hybrid dan satu varietas konvensional tanaman barley pada perlakuan pupuk nitrogen yang berbeda. Hasilnya mampu menangkap keragaman kondisi tanaman di lapang lebih lengkap dibandingkan pengukuran menggunakan perangkat lain seperti SPAD. Kegiatan estimasi kandungan nitrogen dan klorofil pada tanaman kopi robusta juga menggunakan perangkat ImageJ dalam ektrasi data gambar dari 
kamera digital komersial (Putra \& Sony 2017; Putra \& Sony 2018). Pada tanaman jagung penggunaan klorofil meter (SPAD) dan data gambar untuk mengetahui ketersediaan nitrogen tanaman menggunakan data RGB yang diekstrak melalui perangkat ImageJ juga telah dilakukan oleh Milagres et al., (2021).

Chlorophyll fluorescence imaging merupakan salah satu metode deteksi kandungan klorofil tanaman secara non-destruktif menggunakan data gambar. Dalam beberapa tahun terakhir alat ini telah dikembangkan untuk mampu menangkap dua pengukuran kritis yaitu fluorescence minimum dan fluorescence maksimum. Perangkat lunak seperti FLuorescence Imaging Pipeline (FLIP) dibangun dari ImageJ dan phyton yang keduanya merupakan platform open source untuk memproses data gambar hasil chlorophyll fluorescence imaging secara cepat pada level kanopi (Herrit et al., 2021). $\mathrm{Hal}$ ini membuat pengembangan perangkat lunak untuk menganalisis data gambar hasil pemotretan menggunakan kamera digital untuk menduga kandungan klorofil dan nitrogen menjadi sangat mungkin dilakukan.

\section{Perspektif Penggunaan Database Hasil Phenotyping Untuk Pengembangan Robot Pemupuk Nitrogen}

Upaya membangun database melalui teknik phenotyping untuk diintegrasikan ke sistem automasi dalam pengembangan robot berbasis citra gambar sangat mungkin dilakukan dengan pesatnya perkembangan tekologi big data, artificial intelegence, dan machine learning (Hickey et al.,
Untuk pengenalan buah target pada kanopi, sensor visual yang berbeda dan algoritma analisis gambar dipasang pada robot pemanen buah. Data dua dimensi dari buah target telah sukses diperoleh dari kamera monocular, hyperspectral imaging, maupun thermal imaging (Zao et al., 2016). Dalam prosedur deteksi tanaman dan gulma pada robot penyiang, langkah paling penting ialah memisahkan tanaman dan gulma dengan tepat. Metode tradisional umumnya mengambil keuntungan perbedaan fitur tanaman seperti warna atau bentuk, antara tanaman dan gulma. Munculnya teknologi deep learning, membuat lebih banyak lagi peneliti mengaplikasikannya untuk pengenalan tanaman/gulma secara end-to-end (Li et al., 2019).

Penyediaan database untuk menyediakan data bagi pengembangan robot pemupuk nitrogen berbasis vision control disajikan pada Gambar 2 . Tanaman padi diuji pada berbagai tahap pertumbuhan dari vegetatif sampai generatif, serta pada kondisi nitrogen optimal, kelebihan, dan kekurangan melalui kontrol pemupukan. Phenotyping juga dilakukan menggunakan kamera digital pada kondisi terkontrol maupun di lapang. Fluktuasi cahaya yang menjadi isu penting dapat disiasati dengan melakukan phenotyping pada berbagai kondisi cuaca baik pada saat cerah, berawan, mendung serta pada saat pagi, siang, dan sore. Gambar hasil potret kemudian diekstraksi menggunakan perangkat ImageJ dan divalidasi dengan metode baku seperti status nitrogen menggunakan Kjeldahl atau kandungan klorofil menggunakan spektrofotometer. Paramater gambar hasil ekstraksi yang berhubungan kuat

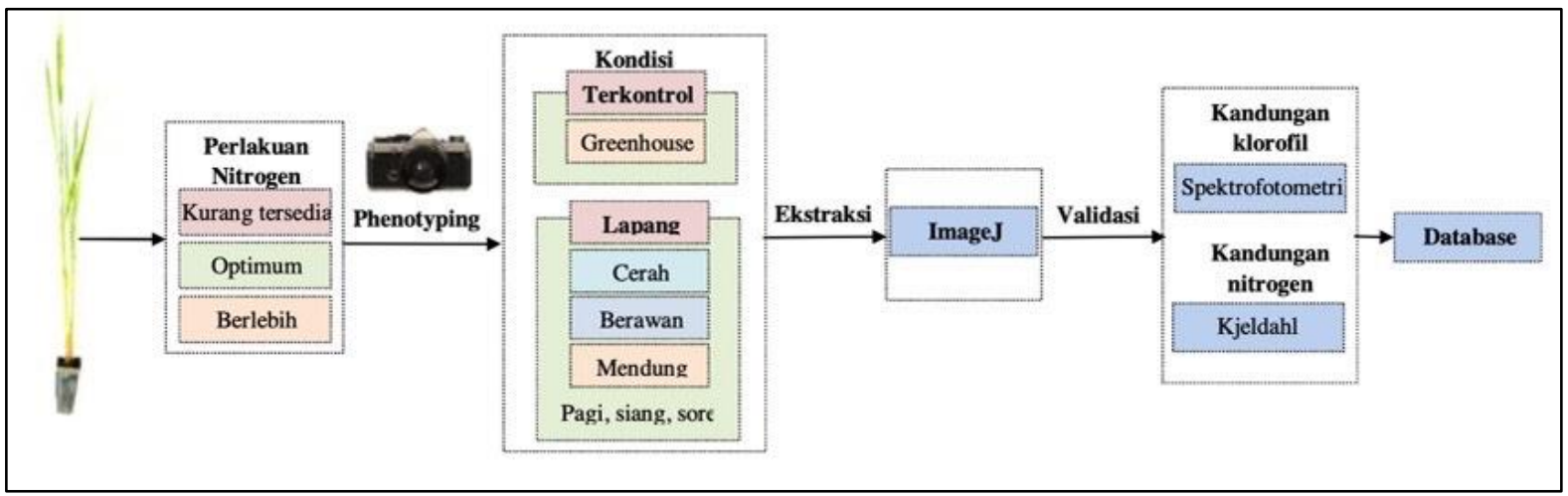

Gambar 2. Pengembangan Database Data Gambar Padi melalui Phenotyping menggunakan Kamera Digital

2019). Pada robot pemanen buah, vision control terdiri dari dua elemen kunci yaitu pengenal buah dan koordinasi eye-hand (eye-hand coordination). dengan hasil pengukuran nitrogen dan klorofil menggunakan pengujian baku kemudian menjadi dijadikan database. 
Integrasi dan penggunaan teknologi sederhana ini memungkinkan untuk para peneliti dengan dukungan dana terbatas atau pada studi pendahuluan dapat menghasilkan data yang akurat. Akurasi data menjadi sangat krusial untuk memastikan training pada implementasi deep learning robot nantinya dapat diandalkan. Lebih lanjut database yang dibangun menggunakan perangkat sederhana seperti kamera digital komersial ini dapat dijadikan pembanding pada saat perangkat yang dianggap lebih baik tersedia.

\section{KESIMPULAN}

Keberadaan database menjadi sangat penting terutama untuk pengembangan robot pemupuk nitrogen tanaman padi berbasis vision control. Progress platform phenotyping yang sangat pesat menggunakan berbagai instrument mulai dari yang simpel sampai yang canggih memudahkan peneliti untuk memilih sesuai kebutuhan. Keberadaan platform ekstraksi data gambar seperti ImageJ yang open source juga memudahkan peneliti untuk melakukan riset phenotyping di berbagai bidang. Eksploitasi teknologi tersebut untuk menciptakan sistem pertanian presisi melalui pengembangan robotic diharapkan mewujudkan Indonesia tahan pangan 2045.

\section{DAFTAR PUSTAKA}

Abu RLA, Basri Z, Made U. (2017). Respon pertumbuhan dan hasil tanaman padi (Oryza sativa L.) terhadap kebutuhan nitrogen menggunakan bagan warna daun. J. Agroland. 24(2): 119-127.

Ata-Ul-Karim, Cao Q, Zhu Y, Tang L, Rehmani MIA, Cao W. (2016). Non- destructive assesment of plant parameters using leaf chlorophyll measurements in rice. Front. Plant Sci. 7(1829): $1-14$.

Adhikari C, Bronson KF, Panuallah GM, Regmi AP, Saha PK, Dobermann A, Olk DC, Hobbs PR, Pasuquin E. (1999). On-farm soil $N$ supply and $N$ nutrition in the rice-wheat system of Nepal and Bangladesh. Field Crops Res. 64:273-286.

Baresel JP, Rischbeck P, Hu Y, Kipp S, Hu Y, Barmeier G, Mistele B. (2017). Use of digital camera as alternative methods for nondestructive detection leaf chlorophyll. Computers and electronics in agriculture. 140: 25-33.
Bloch SE, Ryu M-H, Ozaydin B, Broglie R. (2020). Harnessing atmospheric nitrogen for cereal crop production. Current Opinion in Biotechnology. 62: 181-188.

BPS. (2013). Proyeksi Penduduk Indonesia 20102015. Jakarta. INA: Badan Pusat Statistik.

BPS. (2017). Kajian Konsumsi Bahan Pokok 2017. Jakarta. INA: Badan Pusat Statistik.

BPS. (2018). Luas Panen dan Produksi Beras 2018. Jakarta: Badan Pusat Statistik.

Chawade A, van Ham J, Blomquist $H$, Bagge $O$, Alexandersson E, Ortiz R. (2019). Highthroughput field-phenotyping tools for plant breeding and precision agriculture. Agronomy. 9(258): 1-18.

Cisternas I, Velasquez I, Caro A, Rodriguez A. (2020). Systematic literature review of implementations of precision agriculture. Computers and Electronics in Agriculture. 176(105626): https://doi.org/10.1016/j.compag.2020.105626

Coskun S, Britto DT, Shi W, Kronzucker J. (2017). Nitrogen Transformation in Modern Agriculture and the role of Biological Nitrification Inhibition. Nature Plants. 3(17074): 1-10.

Costa C, Schurr U, Loreto F, Menesatti P, Carpentier S. (2019). Plant Phenotyping Research Trends, a Science Mapping Approach. Front. Plant. Sci.9(1933): 1-11.

Dimkpa, C. O., Fugice, J., Singh, U., \& Lewis, T. D. (2020). Development of fertilizers for enhanced nitrogen use efficiency - Trends and perspectives. Science of The Total Environment, 139113.doi:10.1016/j.scitotenv.2020.139113

Fageria NK, Baligar VC, Jones CA. (2011). Growth and Mineral Nutrition of Field Crops. 3rd edition. Boca Raton: CRC Press.

Herrit MT, Long JC, Roybal MD, Moller Jr DC, Mockler TC, Pauli D, Thompson AL. (2021). FLIP: FLuorescence Imaging Pipline for field-based chlorophyll fluorescence images. SoftwareX. 14. https://doi.org/10.1016/j.softx.2021.100685

Hickey LT, Hafeez AN, Robinson H, Jackson SA, LealBertioli SCM, Tester M, Gao C, Godwin ID, Hayes BJ, Wulff BBH. (2019). Breeding crops to feed 10 billion. Nature Biotechnology. 37: 744-754. 
Kefauver SC, Vicente R, Vergara-Diaz O, FernandezGallego JA, Kerfal S, Lopez A, Melichar JPE, Molins MDS, Araus JL. (2017). Comparative UAV and Field Phenotyping to Assess Yield and Nitrogen Use Efficiency in Hybrid and Conventional Barley. Front. Plant Sci. 8(1733): 115.

Khan MS, Koizumi N, Olds JL. (2019). Biofixation of atmospheric nitrogen in the context of world staple crop production: policy perspectives. Science of the Total Environment. https://doi: https://doi.org/10.1016/j.scitotenv.2019.134945

Lakshmi S, Sivakumar R. (2019). Plant Phenotyping Through Image Analysis Using Nature Inspired Optimization Techniques. dalam Hemanth J, Balas VE (editor). Springer. UK.

Li N, Zhang X, Zhang C, Ge L, He Y, Wu X. (2019). Review of Machine-Vision-Based Plant Detection Technologies for Robotic Weeding. Proceeding of the IEEE International Conference on Robotics and Biomimetics. Dali, China. Desember 2019.

Li Y, Li Y, Zhang H, Wang M, Chen S. (2019). Diazotrophic Paenibacillus beijingensis BJ-18 provides nitrogen for plant and promotes plant growth, nitrogen uptake and metabolism. Front. Microbiol. 10(1119): 1-18.

Mahmud K, Makaju S, Ibrahim R, Missaoui A. (2020). Current progress in nitrogen fixing plants and microbiome research. Plant. 9(97): 1-17.

Mikula, K., Izydorczyk, G., Skrzypczak, D., Mironiuk, M., Moustakas, K., Witek-Krowiak, A., \& Chojnacka, K. (2019). Controlled release micronutrient fertilizers for precision agriculture A review. Science of The Total Environment, 136365.

https://doi.10.1016/i.scitotenv.2019.136365

Milagres CdC, Fontes PCR, de Abreu JAA, da Silva JM, de Figueiredo MN. (2021). Plant growth stage and leaf part to diagnose sweet corn nitrogen status using chlorophyll sensor and scanner image analysis. Journal of Plant Nutrition.

https://doi.org/10.1080/01904167.2021.192119 7.

Monostori I, Arendas T, Hoffman B, Galiba G, Gierzik K, Szira F. (2016). Relationship between SPAD value and grain yield can be affected by cultivar, environment and soil nitrogen content in wheat. Euphytica. 211(1): 103-112.

Munoz-Huerta RF, Guevara-Gonzalez RG, Contreras-Medina LM, Torres- Pacheco I, PradoOlivarez J, Ocampo-Valezquez. (2013). A Review of methods fo sensing nitrogen status in plants: Advantages, disadvantages and recent advances. Sensors. 13(8): 10823-10843.

Nag P, Shriti S, Das S. (2019). Microbiological strategies for enhancing biological nitrogen fixation in nonlegumes. Journal of Applied Microbiology. 1883: 1-13.

Polder G, Blokker G, van der Heijden GWAM. (2012). An ImageJ plugin for plant variety testing. Proceedings of The ImageJ User and Developer Conference 2012. 22-26 Oktober 2012, Luxembourg. pp. 168173.

Pratab A, Gupta S, Nair RM, Gupta SK, Schafleitner R, Basu PS, Singh CM, Prajapati U, Gupta AK, Nayyar H, Mishra AK, Baek K. (2019). Using plant phenomics to exploit the gains of genomics. Agronomy. 9(3): 1-25.

Putra BTW, Soni P. (2017). Enhanced broadband greenness in assesing chlorophyll $a$ and $b$, carotenoid, and nitrogen in robusta coffe plantations using a digital camera. Precision Agric. DOI 10.1007/S11119-017-9513-x.

Putra BTW, Soni P. (2018). Dataset of chlorophyll content estimation of coffea canepora using red and near infra-red consumer grade camera. Data in Brief. 21: 736-741.

Roitsch T, Cabrera-Bosquet L, Fournier A, Ghamkhar K, Jiménez-Berni J, Pinto F, Ober ES. (2019). Review: new sensors and data-driven approaches-a path to the next generation phenomics. Plant Sciences. 282:2-10.

Rueden CT, Eliceiri KW. (2019). ImageJ for the next generation image data. Microsc. Microanal. 25(2): 142-143.

Schindelin J, Rueden CT, Hiner MC, Eliceiri KW. (2015). The ImageJ ecosystem: an open platform for biomedical image analysis. Mol. Reprod. Dev. 82: 518-529.

Soucek J, Prazan R, Velebil J. (2019). Effect of nitrogen fertilization on the color of wheat leaves as an indicator of application deficiency. 
$7^{\text {th }}$ TAE. 17-20 September 2019. Prague, Czech Republic.pp.524-528.

Varinderpal-Singh, Bijay-Singh, Yavinder-Singh, Thind HS, Gupta RK. (2010). Need based nitrogen management using the chlorophyll meter and leaf colour chart in rice and wheat in South Asia: A review. Nutr Cycl Agroecosyst. 88: 361-380.
Walter A, Liebisch F, Hund A. (2015). Plant phenotyping: From bean weighing to image analysis. Plant Methods. 11(14): 1-11. 